\title{
PENGARUH MODEL PEMBELAJARAN TIME TOKEN TERHADAP HASIL BELAJAR SISWA PADA MATERI POKOK MENAPAKI JALAN TERJAL PENEGAKAN HAM DI INDONESIA DI KELAS XI SEMESTER I SMA NEGERI SIPAHUTAR TAPUT TAHUN AJARAN 2020/2021
}

\author{
Oleh: \\ Lukman Pardede ${ }^{1)}$ \\ Dewi Lestari Pardede ${ }^{2)}$ \\ Universitas HKBP Nomensen, Medan \\ STINDO, Medan ${ }^{1,2)}$ \\ E-mail: \\ $\frac{\text { lukmanpardede1961@ gmail.com }}{{ }^{1)}}$
}

\begin{abstract}
This study is categorized into quasi-experimental research, a research aiming at determining whether there is an influence or consequence of something that is caused to the subject, namely students. The samples taken in this study are divided into two experimental classes and control classes, these two classes received different treatment. The experimental class was given the Time Token learning model and the control class learning model was given directly. The learning outcomes of students who were taught using the Time Token learning model on the subject matter of treading the steep path of human rights enforcement in class XI in the first semester of SMA NEGERI SIPAHUTAR TAPUT Academic Year 2020/2021 are 78,83 The learning outcomes of students who are taught using a direct learning model on the subject matter of treading a steep road to upholding human rights in Indonesia in class XI semester I SMA NEGERI SIPAHUTAR TAPUT FY 2020/2021 are 75.50. There is a significant effect of using the Time Token learning model on learning outcomes students in the subject matter tread a steep road to upholding human rights in Indonesia in class XI semester I SMA NEGERI SIPAHUTAR TAPUT FY 2020/2021 this is indicated by the results of statistical tests $\left(t\right.$ test) $t_{\text {count }}>t_{\text {table }}(1.89>1,67)$.
\end{abstract}

Keywords: Learning Model, Time Token, Learning Outcomes

\begin{abstract}
ABSTRAK
Jenis penelitian ini adalah penelitian eksperimen semu, yaitu penelitian yang bertujuan untuk mengetahui ada tidaknya pengaruh atau akibat dari suatu yang ditimbulkan pada subjek yaitu siswa. Sampel yang diambil dalam penelitian ini dibagi atas dua kelas eksperimen dan kelas kontrol, kedua kelas ini mendapat perlakuan yang berbeda. Kelas eksperimen diberikan Model pembelajaran Time Token dan kelas kontrol diberikan model pembelajaran langsung.Hasil belajar siswa yang diajarkan dengan menggunakan model pembelajaran Time Token pada materi pokok menapaki jalan terjal penegakan HAM di Indonesia di kelas XI semester I SMA NEGERI SIPAHUTAR TAPUT T.A 2020/2021 adalah78,83.Hasil belajar siswa yang diajarkan dengan menggunakan model pembelajaran langsung pada materi pokok menapaki jalan terjal penegakan HAM di Indonesia di kelas XI semester I SMA NEGERI SIPAHUTAR TAPUT T.A 2020/2021 adalah75,50.Ada pengaruh yang signifikan penggunaan model pembelajaran Time Token terhadap hasil belajar siswa pada materi pokok menapaki jalan terjal penegakan HAM di Indonesia di kelas XI semester I SMA NEGERI
\end{abstract}


SIPAHUTAR TAPUT T.A 2020/2021 hal ini ditunjukkan dengan hasil uji statistic (uji t) $t_{\text {hitung }}>t_{\text {tabel }}(1,89>1,67)$.

Kata Kunci:Model Pembelajaran, Time Token, Hasil Belajar

\section{PENDAHULUAN}

Sistem pendidikan memberikan suatu upaya dalam mendewasakan pikiran dan sikap siswa dalam pembelajaran. Pendidikan adalah suatu tindakan yang mengupayakan segala pelatian berupa bimbingan untuk perubahan peserta didik dalam belajar mengajar di dalam kelas. Hal ini dilakuka untuk mengembangkan kecerdasaan anak bangsa dari dini sehingga mampu memberikan penyelesaian dari masalah yang dihadapi seperti pemecahan masalah dalam hidup. Disatu pihak pendidikan mempersiapkan peserta didik untuk menjadi manusia dengan perilaku yang sesuai dengan nilai, norma, dan peraturan yang berlaku di masyarakat. Peserta didik harus harus mematuhi falsafah hidup yang dianut oleh bangsa dan negaranya.

Danim (2010:2) menyatakan bahwa:pendidikan adalah proses pemartabatan manusia menuju puncak optimasi potensi kognitif, afektif, dan psikomotorik yang dimilikinya. Pendidikan juga merupakan proses membimbing, melatih dan memudahkan manusia terhindar atau keluar dari kebodohan dan pembodohan serta metamorphosis perilaku menuju kedewasaan sejati.

Peningkatan mutu pendidikan sangat berkaitan erat dengan proses pendidikan yang terjadi dalam kegiatan belajar mengajar siswa akan memahami materi pelajaran yang baik apabiala harus terjadi kerja sama antara guru dengan siswa. Dalam penyajian materi seorang guru harus pandai memilih model, pendekatan, strategi, dan media yang tepat serta cara pengasahan kelas yang sesuai dengan kondisi siswa agar siswa tidak merasa bosan.

Adapun tujuan belajar bagi siswa adalah sebagai berikut: a) Melibatkan siswa dalam sebuah proses interaksi dengan siswa lainnya baik secara fisik,non fisik, fisik, dan intelektual.

b) Bertambahnya pengetahuan, kemampuan dan keterampilan yang bermanfaat bagi siswa sesuai dengan tingkat perkembangannya.

c) Meningkatkan daya nalar siswa.

d) Siswa mampu menguasai strategi individual dan menekankan pada pengembangan proses berpikir tinggi.

Dari pengalaman penulis sejak duduk di tingkat SMP, SMA, bahkan saat PPL penulis menemukan berbagai maslah di dalam mata pembelajaran PKn dan kenyataannya (1) Siswa kurang atau tidak percaya diri jika diminta intuk mengemukakan pendapat, (2) Kurangnya minat dan motivasi siswa untuk mempelajari PKn, (3) Model pembelajaran yang kurang bervariasi, (4) Siswa pasif dalam kegiatan pembelajaran (5 ) Rendahnya hasi belajar siswa khususnya dalam mata pelajaran PKn.

Untuk mengatasi masalah pembelajaran yang dihadapi guru dan tercapainya tujuan pembelajaran, guru perlu melakukan variasi dan modivikasi pembelajaran dan solisinya yaitu menerapkan model pembelajaran yang dapat meningkatkan hasil belajar yang lebih baik, salah satunya yaitu dengan menggunakan model pembelajaran Time Token.

\section{TINJAUAN PUSTAKA}

A. Kajian Teoritis

1. Hakikat Belajar Dan Hasil Belajar

a. Pengertian Belajar 
Mendapatkan suatu pendidikan akan memberikan dampak positif. Pendidikan beurpa suatu belajar yang ditanamkan sedari diri. Belajar merupakan hal yang tidak terlepas dari diri manusia karena tidak terbatas oleh ruang dan waktu. Pengalaman yang paling utama dari belajar dapat diperoleh ketika dari dini yaitu sejak lahir. Secara psikologis, belajar merupakan suatu perkembangan tingkah laku yang di dapatkan dari keluarga dan lingkungan masyarakat.

Menurut Slamet (2010:2), menyatakan bahwa, belajar yaitu proses pengalaman yang di dapatkan manusia dari masyarakat sehingga mengalami perkembangan kognitif, afektif, dan psikomotorik.

Sedangkan, Winkle (2016:4), mengatakan, belajar merupakan proses aktiftas untuk pembentukan mental karena langsung berinteraksi dengan lingkungannya sehingga mengalami banyak perubahan baik sikap, pengetahuan, pengalaman, dan lain-lain.

Dari pendapat para ahli di atas dapat disimpulkan bahwa belajar merupakan usaha yang dilakukan individu untuk memperoleh perubahan tingkah laku yang baru secara keseluruhan, sebagai pengalaman individu itu sendiri dalam interaksi dengan lingkungannya seta suatu aktivitas mental yang berlangsung dalam interaksi aktif antar seseorang dengan lingkungannya yang menghasilkan perubahan-perubahan dalam pengetahuan, pemahaman, keterampilan dan nilai sikap yang bersifat relative konstan dan berbekas.

b. Pengertian Hasil Belajar

Hasil belajar sering kali digunakan sebagai ukuran untuk mengetahui seberapa jauh seseorang menguasai bahan yang sudah diajarkan. Menurut Mudjiono (2011:5) menyatakan bahwa : "Hasil belajar merupakan hasil dari suatu interaksi tindak belajar dan tindak mengajar. Menurut Sudjana (2011:22) menyatakan bahwa : "Hasil belajar adalah kemampuan-kemampuan yang dimiliki siswa setelah dia menerima pengalaman belajar".

Dari beberapa pendapat yang dikemukakan oleh para ahli di atas maka peneliti dapat menyimpulkan bahwa keberhasilan belajar bukanlah semata-mata keberhasilan dari segi kognitif, tetapi mesti melumat aspek-aspek lain, seperti aspek afektif dan aspek psikomotorik.

c. Faktor-faktor Yang Mempengaruhi Belajar dan Hasil Belajar

Dalam belajar ada banyak yang mempengaruhi seorang anak atau siswa dalam melakukan aktifitas belajar. Menurut Slameto (2013:54) Faktor-faktor yang mempengaruhi hasil belajar tersebut, yaitu :

1) Faktor internal

a) Faktor jasmaniah (kesehatan, cacat tubuh)

b) Faktor psikologis (intelegensi, perhatian, minat, bakat, motif, kematangan, kesiapan)

c) Faktor kelelahan

2) faktor eksternal

a) Faktor keluarga (cara orangtua mendidik, relasi antar keluarga, suasana rumah, keadaan ekonomi keluarga, pengertian orangtua, latar belakang kebudayaan)

b) Faktor sekolah (metode mengajar, kurikulum, relasi guru dengan siswa, relasi siswa dengan siswa, disiplin sekolah, alat pelajaran, waktu sekolah, standart pelajaran diatas ukuran, keadaan gedung, metode belajar, tugas rumah)

c) Faktor masuarakat (kegiatan siswa dalam masyarakat, media massa, teman bergaul, bentuk kehidupan masyarakat.

Selanjutnya Menurut Bloom, dkk dalam Aunurrahman (2012:49) 
Penggolongan atau tingkatan jenis perilaku yang mempengaruhi hasil belajar terdiri dari tiga ranah atau kawasan, yaitu :

1. Ranah kognitif terdiri dari enam jenis, yaitu :

a. Pengetahuan, mencakup kemampuan ingatan tentang hal-hal yang telah dipelajari dan tersimpan di dalam ingatan.

b. Pemahaman, mencakup kemampuan menangkap sari dan makna hal-hal yang dipelajari.

c. Penerapan, mencakup kemampuan menerapkan metode, kaidah untuk menghadapi masalah yang nyata dan baru.

d. Analisis, mencakup kemampuan merinci suatu kesatuan ke dalam bagianbagian sehingga struktur keseluruhan dapat dipahami dengan baik.

e. Sintesis, mencakup kemampuan membentuk suatu pola baru, misalnya tampak di dalam kemampuan menyusun suatu program kerja.

f. Evaluasi, mencakup kemampuan membentuk pendapat tentang beberapahal berdasarkan kriteria tertentu.

2. Ranah Afektif terdiri dari lima jenis perilaku, yaitu:

a. Penerimaan, yang mencakup kepekaan tentang hal-hal tertentu dan kesediaan memperhatikan hal tersebut.

b. Partisipasi, yang mencakup kerelaan, kesediaan, memperhatikan dan berpartisipasi dalam suatu kegiatan.

c. Penilaian dan penentuan sikap yang mencakup penerimaan terhadap suatu nilai, menghargai, mengakui, dan meneetukan sikap. d. Organisasi, yang mencakup kemampuan membentuk kemampuan membentuk suatu sistem nilai sebagai pedoman dan pegangan hidup.

e. Pembentukan pola hidup, yang mencakup kemampuan menghayati nilai,dan membentuknya menjadi pola nilai kehidupan pribadi.

3. Ranah psikomotorik terdiri dari tujuh perilaku, yaitu :

a. Persepsi, yang mencakup mendeskripsikan sesuatu secara khusus dan menyadari adnya perbedaan antara sesuatu tersebut.

b. Kesiapan, yang mencakup kemampuan menempatkan diri dalam suatu keadaan dimana akan terjadisuatu gerakan atau rangkaian gerakan, kemampuan ini mencakup aktivitas jasmani dan rahani (mental).

c. Gerakan terbimbing, mencakup kemampuan melakukan gerakan sesuai contoh atau gerakan peniruan.

d. Gerakan terbiasa, mencakup kemampuan melakukan gerakan-gerakan tanpa contoh.

e. Gerakan kompleks, yang mencakup kemampuan melakukan gerakan atau keterampilan yang terdiri dari banyak tahap secara lancar, efisien, dan tepat.

f. Penyesuaian pola gerakan, yang mencakup kemampuan mengadakan perubahan dan penyesuaian pola gerak-gerik dengan persyaratan khusus yang berlaku.

g. Kreativitas, mencakup kemampuan melahirkan polapola gerak-gerik yang baru atas prakarsa sendiri.

Dari beberapa pendapat yang dikemukakan oleh para ahli di atas maka 
peneliti dapat menyimpulkan bahwa faktor-faktor dan tingkatan jenis perilaku yang mempengaruhi hasil belajar sangat erat kaitannya dengan hasil hasil belajar. hasil belajar merupakan daya penggerak dan pendorong dari dalam maupun dari luar diri siswa yang dapat menimbulkan kegiatan belajar sehingga tujuan yang dikehendaki oleh siswa dapat tercapai yang mencerminkan adanya kebutuhan untuk belajar, adanya keinginan berhasil, adanya keinginan untuk mencapai kesuksesan atau menghindari kegagalan, adanya keinginan untuk berperestasidan adanya suatu usaha untuk mempengaruhi perilaku seseorang agar mengarah pada tujuan yang diinginkan.

Untuk mencapai perubahan yang diharapkan, baik perubahn pada aspek atau ranah kognitif, afektif maupun psikomotorik, maka belajar hendaknya memperhatikan secara sungguh-sungguh beberapa prinsip yang dapat mendukung terwujudnya hasil belajar yang diinginkan serta dalam suatu keluarga terdapat perhatian orang tua yang kurang terhadap anaknya dan kebiasaan sehari-hari berperilaku yang kurang baik dari orang tua dalam kehidupan sehari-hari berpengaruh juga terhadap hasil belajar siswa.

\section{Model Pembelajaran Time Token}

a. Pengertian Model pembelajaran Time Token

Eliyana dalam Shomin (2014 : 216), menyatakan bahwa:

Time Token adalah salah satu tipe pembelajaran kooperatif.Sistem mengajar akan diberikan pembentukan kelompok dengan bervariasi sehningga peserta didik tidak hanya menoton hanya dikenalnya atau teman dekatnya. Hal ini akan membantu peserta didik untuk meningkatkan rasa sosialnya satu dengan yang lain.

Sedangkan menurut Arends dalam Shoimin (2017:239), menyatakan bahwa:
Model pembelajaran Time Token merupakan siswaselalu dilibatkan secara aktif dan disitu guru berperan mengajak siswa mencari solusi bersama tehadap permasalahan yang ditemui.

Berdasarkan beberapa pendapat di atas dapat disimpulkan bahwa Time Token adalah tipe pembelajaran kooperatif dimana siswa dibentuk kedalam kelompok belajar yang didalamnya mengajarkan keterampilan sosial untuk menghindarkan siswa diam sama sekali dan berdiskusi dan model ini juga merupakan contoh kecil dari penerapan pembelajaran demokratis di sekolah yang menempatkan siswa sebagai subjek.

b. Langkah-langkah Model Pembelajaran Time Token

Adapun langkah-langkah yang harus di lakukan untuk melakukan pembelajaran dengan model pembelajaran Time Token menurut Shoimin (2016:216-217) adalah sebagai berikut:

1) Guru menjelaskan tujuan pembelajaran.

2) Guru mengondisikan kelas untuk melaksanakan diskusi .

3) Guru memberi tugas pada siswa.

4) Guru memberi sejumlah kupon berbicara dengan waktu \pm 30 detik per kupon pada setiap siswa.

5) Guru memberi sejumlah nilai berdasarkan waktu yang di gunakan tiap siswa.

c. Kelebihan dan kekurangan Model Pembelajaran Time Token

1) Kelebihan Model Pembelajaran Time Token

Shoimin

(2014:217-218) menyatakan bahwa suatu model pembelajaran memiliki kelebihan. Adapun kelebihan model pembelajaran Time Token tersebut adalah sebagai berikut : 
a) Mendorong siswa untuk meningkarkan inisiatif dan partisipasi.

b) Siswa tidak mendominasi pembicaraan atau diam sama sekali.

c) Siswa menjadi aktif dalam kegiatan pembelajaran.

d) Meningkatkan kemampuan siswa dalam berkomunikasi (aspek berbicara).

e) Melatih siswa mengungkapkan pendapatnya.

f) Menumbuhkan kebiasaan pada siswa untuk saling mendengarkan, berrbagi, memberikan masukan, dan keterbukaan terhadap kritik.

g) Mengajarkan siswa untuk menghargai pendapat orang lain.

h) Guru dapat berperan untuk mengajak siswa mencari solusi bersama terhadap permasalahan yang ditemui.

i) Tidak memerlukan banyak media pembelajaran.

2) Kekurangan model pembelajaran Time Token

Adapun kekurangan model pembelajatan Time Token menurut Shoimin (2016:218) adalah sebagai berikut:

a) Hanya dapat digunakan untuk mata pelajaran tertetu saja.

b) Tidak bisa digunakan pada kelas yang jumlah siswanya banyak.

c) Memerlukan banyak waktu untuk persiapan dalam proses pembelajaran karna semua siswa harus berbicara satu per satu sesuai jumlah kupon yang dimilikinya.

d) Siswa yang aktif tidak bisa mendominasi dalam kegiatan pembelajaran.

\section{Model Pembelajaran Langsung}
a. Pengertian
Pembelajaran
Langsung

Fathurrohman (2015:167) mengatakan bahwa: "pembelajaran langsung merupakan suatu model pendekatan mengajar yang dapat membantu siswa di dalam mempelajari dan menguasai keterampilan dasar serta memperoleh informasi selangkah demi selangkah".

Sedangkan menurut Arend dalam Shoimin (2016:64) mengatakan bahwa: "pembelajaran langsung adalah model pembelajaran yang dirancang khusus untuk menunjang proses belajar siswa yang berkaitan dengan pelajaran deklaratif dan pengetahuan.

Langkah-langkah Pembelajaran Model Pembelajarn Langsung

Fathurrohman, (2015:172) Langkahlangkah pembelajaran model pengajaran langsung pada dasarnya mengikuti polapola pembelajaran secara umum yaitu :

1) Menyusun rancangan pembelajran yang dibarengi dengan motifasi belajar

2) Memberikan suatu tujuan belajar yang relevan.

3) Presentasi dan demonstrasi. Guru melakukan presentasi atau demonstrasi pengetahuan dan keterampilan.

4) Mencapai kejelasan. Hasil-hasil penelitian secara konsisten menunjukkan bahwa kemampuan guru umtuk memberikan informasi yang jelas dan spesifik kepada siswa, mempunyai damppak yang positif terhadap proses belajar mengajar.

5) Melakukan demonstrasi. Pengajaran langsung berpegang teguh kepada asumsi bahwa sebagian besar yang dipelajari (hasil belajar) berasal dari mengamati orang lain.

6) Memperoleh pencapaian dalam memahamai dan menguasai sehingga guru berupaya agar segala sesuatu yang prlu didemonstrasikan juga benar. 
7) Berlatih. Agar dapat mendemonstrasikan sesuatu dengan benar diperlukan latihan yang intensif dan memerhatikan aspek-aspek penting dari keterampilan atau konsep ynag didemonstrasikan.

8) Memberikan latihan terbimbing. Keterlibatan siswa secara aktif dalam pelatihan dapat meningkatkan retensi, membuat belajar langsung dengan lancer, dan memungkinkan siswa menerapkan konsep atau keterampilan pada situasi yang baru.

c. Kelebihan dan Kekurangan Model Pembelajaran Langsung

1) Kelebihan Model Fathurrohman (2015:176), menatakan bahwa kelebihan model pembelajaran langsung antara lain sebagai berikut:

a) Dengan model pembelajaran langsung,guru mengendalikan isi materi dan urutan informasi yang diterima oleh siswa sehingga dapat mempertahankan focus mengenai apa yang harus dicapai oleh siswa.

b) Dapat diterapkan secara efektif dalam kelas yang besar maupun yang kecil.

c) Dapat digunakan untuk menekankan poin-poin penting atau kesulitankesulitan yang mungin dihadapi siswa sehingga hal-hal tersebut dapat diungkapkan.

d) Dapat menjadi cara yang efektif untuk mengajarkan informasi dan pengetahuan faktual yang sangat terstruktur. e) Merupakan cara yang paling efektif untuk mengajarkan konsep dan keterampilan-keterampilan yang eksplisit kepada siswa yang berpartisipasi rendah.

f) Dapat menjadi cara untuk menyampaikan informasi yang banyak dalam waktu yang relatif singkat yang dapat diakses secara setara olehseluruh siswa.

g) Memungkinkan guru untuk menyampaikan ketertarikan pribadi mengenai materi pelajaran (melalui presentasi yang antusias) yang dapat merangsang ketertarikan dan antusiasime siswa.

h) Ceramah merupakan cara yang bermanfaat untuk menyampaikan informasi kepada siswa yang tidak suka membaca atau yang tidak memiliki keterampilan dalam menyusun dan menafsirkan informasi.

i) Secara umum ceramah adalah cara yang paling memungkinkan untuk menciptakan lingkungan yang tidak mengancam dan bebas stress bagi siswa.

j) Model pembelajaran langsung dapat digunakan untuk membangun model pembelajaran dalam bidanf tertentu.

2) Kekurangan Model Pembelajaran Langsung

Adapun kekurangan model pembelajaran langsung menurut Fathurrohman (2015:178-179) antara lain sebagai berikut :
a) Model
pembelajaran langsung bersandar pada kemampuan siswa untuk mengasimilasikan informasi 
melalui kegiatan mendengarkan, mengamati, dan mencatat. Oleh karena tidak semua siswa memiliki keterampilan dalam hal-hal tersebut, guru harus masih mengajarkannya kepada siswa.

b) Dalam model pembelajaran langsung, sulit untuk mengatasi perbedaan dalam hal kemampuan, pengetahuan awal, tingkat pembelajaran, dan pemahaman, gaya belajar, atau ketertarikan siswa.

c) Karena siswa hanya memiliki sedikit kesempatan untuk terlibat secara aktif, sulit bagi siswa untuk mengembangkan keterampilan sosial dan interpersonal mereka.

d) Jika materi yang disampaikan bersifat kompleks, rinci, atau abstrak, model pembelajaran langsung mungkin tidak dapat memberi siswa kesempatan yang cukup untuk memproses dan memahami informasi yang disampaikan.

e) Model pembelajaran langsung member siswa cara pandang guru mengenai bagaimana materi disusun dan disintesis, yang tidak selalu dapat dipahami atau dikuasai oleh siswa.

f) Jika model pembelajaran langsung tidak banyak melibatkan siswa, siswa akan kehilangan perhatian setelah 10-15 menit dan hanya akan mengingat sedikit isi materi yang disampaikan. g) Jika terlalu sering digunakan, model pembelajaran langsung akan membuat siswa percaya bahwa guru akan memberitahu mereka mereka semua yang perlu mereka ketahui. Hal ini akan menghilangkan rasa tanggung jawab mengenai pembelajaran mereka sendiri.

h) Karena model pembelajaran langsung melibatkan banyak komunikasi satu arah, guru sulit untuk mendapatkan umpan balik mengenai pemahaman siswa. Hal ini dapat membuat siswa tidak paham atau salah paham.

i) Demonstrasi sangat bergantung pada keterampilan pengamatan siswa. Sayangnya, banyak siswa bukanlah pengamat yang baik sehingga dapat melewatkan hal-hal yang dimagsudkan oleh guru.

\section{Materi Pokok}

A. Kasus Pelanggaran HAM

1. Pengertian pelanggaran Hak Asasi Manusia dan Bentukbentuk Pelanggaran HAM

Secara yuridis menururt pasal 1 angka 6 UU RI No.39 tahun 1999 tentang Hak Asasi manuasi yang dimaksud dengan pelanggaraan hak asasi manusia adalah setiap perbuatan seseorang atau kelompok

Dalam kehidupan sehari-hari, kalian tentunya pernah mendengar atau membaca berita tentang kasus pembunuhan, pemerkosaan penculikan dan sebagainya, itu merupakan bentuk pelanggaran yang terjadi di masyarakat.

Bentuk pelanggaran biasanya terjadi dalam 2 bentuk sebagai berikut :

a. Diskriminasi , yaitu suatu pembatasan, pelecehan atau pengucilan yang langsung maupun tidak langsung 
didasarkan pada pembedaan manusia atas dasar agama, suku, ras, etnik, kelompok, golongan, jenis kelamin, bahasa, keyakinan dan politik yang berakibat pengurangan, penyimpangan atau pengapusan manusia dan kebebasan dasar dalam kehidupan baik secara individual maupun kolektif dalam semua aspek kehidupan.

b. Penyiksaan adalah suatu perbuatan yang dilakukan dengan sengaja sehingga menimbulkan rasa sakit atau penderitaan baik jasmani maupun rohani pada seseorang untuk memperoleh pengakuan atau keterangan dari seseorang atau orang ketiga.

\section{B. Contoh kasus pelanggaran HAM di Indonesia}

1. Penyebab Pelanggaran Hak Asasi Manusia

Materi yang disampaikan pada minggu kedua ini adalah tentang Contoh kasus pelanggaran Hak Asasi Manusia di Indonesia.

Pelanggaran HAM disebabkan oleh faktor-faktor berikut :

a. Faktor Internal, yaitu dorongan untuk melakukan pelanggaran HAM yang berasal dari diri pelaku pelanggar HAM, diantaranya adalah :

1. Mengutamakan diri sendiri

2. Rendahnya kesadaran HAM.

3. Sikap tidak toleran.

b. faktor eksternal, yaitu faktor-faktor diluar diri manusia yang mendorong seseorang atau sekelompok orang melakukan pelanggaran HAM, diantaranya sebagai berikut:

1. Penyalahgunaan kekuasan.

2. Ketidaktegasan aparat penegak hukum.

3. Penyalahgunaan teknologi.

4. Kesenjangan sosial dan ekonomi yang tinggi.

\section{Kasus pelanggaran HAM di Indonesia}

Di indonesia, meskipun pemmerintah telah mengeluarkan peraturan perundang-undangan mengenai HAM, namun pelanggaran HAM tetap selalu ada baik yang dilakukan oleh pemerintah maupun oleh masyarakat sendiri.

Adapun kasus HAM yaitu:

a. Kerusuhan Tanjung Priok tanggal 12 september 1984.

b. Penyerbuan kantor partai demokrasi indonesia tanggal 20 juli 1996.

c. Penembakan mahasiswa universitas trisakti pada tanggal 12 mei 1998.

d. Tragedi semanggi 1 pada tanggal 13 november 1998.

e. Penculikan aktivis pada bulan april 1997-april 1999.

f. Meninggalnya munir yang merupakan aktivis HAM Indonesia,pada tanggal 7 september 2004.

\section{Upaya Penegakan HAM}

1. Upaya pemerintah dalam menegakkan HAM

Selain mengacu pada peraturan perundang-undangan nasional, proses penegakan HAM di Indonesia juga mengacu pada ketentuan-ketentuan hukum internasional yang pada dasarnya memberikan wewenang luar biasa kepada setiap negara. Bahkan, ada pertimbangan dari Idrus untuk HAM yaitu

a. Kedudukan negara Indonesia sebagai negara yang berdaulat baik secara hukum, sosial, politik, harus di pertahankan dalam keadaan apapun sesuai dengan prinsip-prinsip dalam Piagam PBB.

b. Dalam pelaksanaanya, pemerintah harus tetap mengacu kepada ketentuan-ketentuan hukum internasional mengenai HAM.

\section{Upaya penanganan kasus} pelanggaran HAM

a. pengupayaan dalam mencegah pelanggaran HAM

a) Supremasi hukum dan demokrasi harus ditegakkan.

b) Meningkatkan kualitas pelayanan publik untuk mencegah terjadinya 
berbagai bentuk pelanggaran HAM oleh pemerintah.

c) Meningkatkan pengawasan dari masyarakat dan lembaga-lembaga politik terhadap setiap upaya penegakan HAM.

b. Penanganan kasus pelanggaran HAM di pengadilan HAM

Kasus pelanggaran HAM senantiasa terjadi jika tidak secepatnya ditangani. Kasus pelanggaran HAM yang terjadi di negara tersebut akan disidangkan oleh Mahkamah Internasional.Sebagai negara hukum dan beradab tentu saja indonesia juga mau disebut sebagai unwilling state.

\section{METODE PENELITIAN}

Penelitian dilakukan dengan metode eksperimen semu.Kelas eksperimen diberikan Model pembelajaran
Time Token dan kelas kontrol diberikan model pembelajaran langsung.

\section{HASIL DAN PEMBAHASAN}

\section{A. Hasilpenelitian}

Penelitian ini menerapkan pembelajaran dengan menggunakan model pembelajaran Time Token dalam Upaya meningkatkan hasil belajar siswa pada materi pokok menapaki jalan terjal penegak HAM di Indonesia T.A 2020/2021 7.

\section{B. Deskripsi data penelitian}

1. Pretes Hasil Belajar Siswa Kelas Eksperimen Dan Kelas Kontrol

Berdasarkan data yang diperoleh dari hasil pemberian pretes pada kelas eksperimen diperoleh nilai rata-rata 51,66 dengan standar deviasi 11,54 dan pada kelas control diperoleh nilai rata-rata 45,66 dengan standar deviasi 18,39.

\section{Diagram 4.1.Hasil pretes Kelas Eksperimen Dan KelasKontrol}

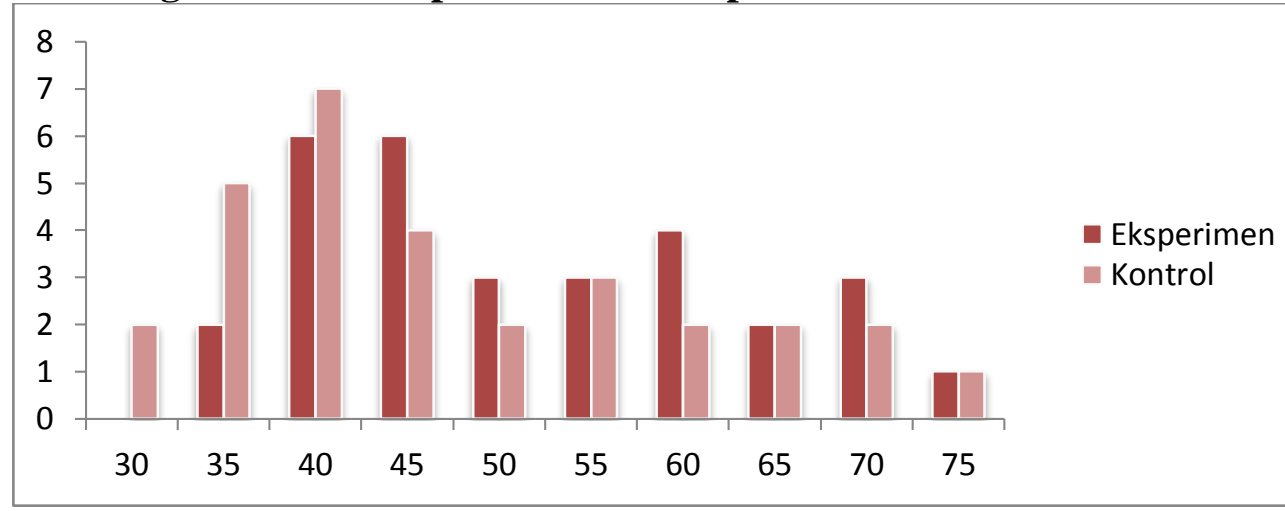

2. PostesHasilBelajarSiswaKelasEksperimen Dan KelasKontrol

Berdasarkan data yang diperoleh dari hasil pemberian postes pada kelas eksperimen diperoleh nilai rata-rata 78,83dengan standar deviasi 6,78dan pada kelas control diperoleh nilai rata-rata 75,5 dengan standar deviasi 6,83.

\section{Diagram 4.2.Hasil postestKelasEksperimen Dan KelasKontrol}

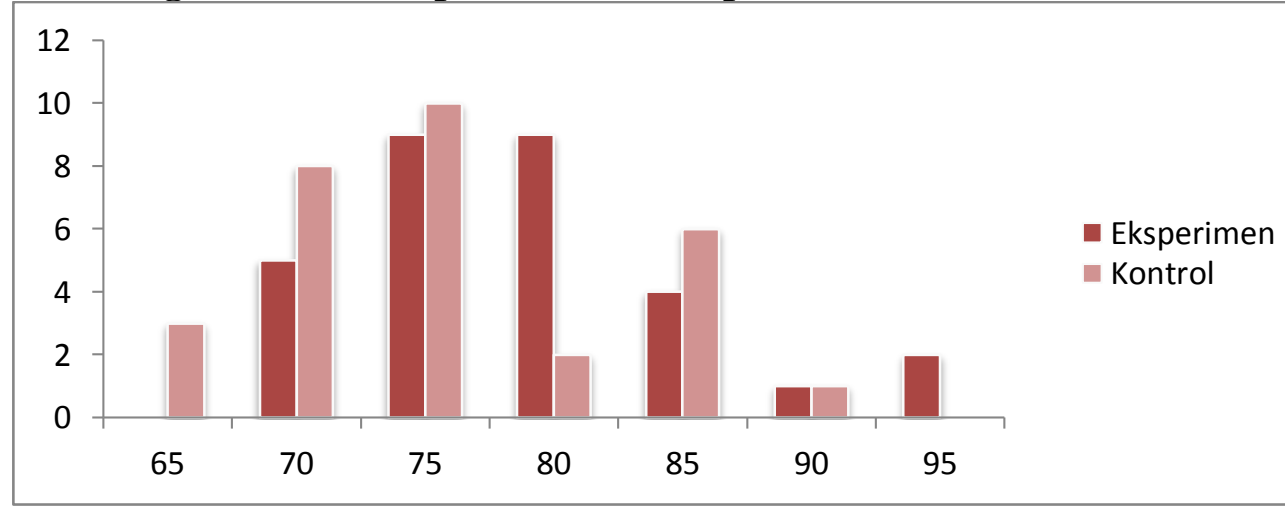




\section{Uji persyaratan analisis data}

Uji persyaratan analisis data meliputi uji normalitas dan uji homogenitas terhadap data pretes dan postes pada kedua kelas penelitian .berikut ini disajikan hasil uji persyaratan pada kedua penelitian.

1. Ujinormalitas
Uji normalitas bertujuan untuk mengetahui apakah data setiap variable berdistribusi normal atau tidak. Pengujian ini dilakukan dengan menggunakan rumus liliefors. Data untuk setiap variable dikatakan normal apabila $l_{\text {hitung }}<l_{\text {tabel }}$ pada taraf signifikan.

Tabel 4.3 Pengujian Normalitas Data Penelitian

\begin{tabular}{|c|c|c|c|c|c|}
\hline No & Kelas & Data & $l_{\text {hitung }}$ & $l_{\text {tabel }}$ & Keterangan \\
\hline \multirow{2}{*}{1} & Eksperimen & Pretes & 0,106 & \multirow{2}{*}{0,161} & Normal \\
\cline { 2 - 4 } & & Postes & 0,149 & & Normal \\
\cline { 2 - 4 } & Kontrol & Pretes & 1,118 & & Normal \\
\cline { 2 - 4 } & & Postes & 1,109 & & Normal \\
\hline
\end{tabular}

Dengan mengkonsultasikan hasil perhitungan $l_{\text {hitung }}$ dengan $l_{\text {tabel }}$ dari 30 responden adalah sebesar 0,161 dan kriterial $l_{\text {hitung }}<l_{\text {tabel }}$ maka dapat disimpulkan bahwa data masing masing variable berdistribusi normal. Penghitungan uji mormalitas dapat dilihat pada lampiran 13.
2. Ujihomogenitas

Uji homogenitas dilakukan dengan uji varians. Uji homogenitas dilakukan untuk mengetahui apakah data pada kedua kelompok penelitian homogen. Ringkasan hasil penelitian uji homogenitas ditunjukkan pada table berikut :

Tabel 4.4 Pengujian homogenitas data penelitian

\begin{tabular}{|c|c|c|c|c|c|c|}
\hline No & Kelas & Data & Varians & $F_{\text {hitung }}$ & $F_{\text {tabel }}$ & Keterangan \\
\hline \multirow{2}{*}{1} & Eksperimen & Pretes & 207,072 & 1,55 & \multirow{2}{*}{0,160} & \multirow{2}{*}{ Homogen } \\
\cline { 2 - 4 } & & Postes & 133,171 & & \\
\cline { 2 - 4 } 2 & Kontrol & Pretes & 46,774 & 1,01 & & \\
\cline { 2 - 4 } & & Postes & 45,995 & & & \\
\hline
\end{tabular}

Dari tabel di atas diperoleh bahwa $F_{\text {hitung }}<F_{\text {tabel }}$ sehingga dapat disimpulkan bahwa data pada masingmasing kelompok penelitian adalah homogen. Penghitungan uji homogenitas data dapat dilihat pada lampiran 14 .

\section{UjiHipotesisPenelitian}

Setelah data memenuhi persyaratan homogenitas dan normalitas maka pengujian hipotesis dalam penelitian ini menggunakan uji beda.

1. Pengujiankemampuanawal

Tabel 4.5 hasilujihipetesisnilai pre test

\begin{tabular}{|l|c|c|c|c|c|}
\hline No & Data kelas & Nilai rata-rata & $t_{\text {hitung }}$ & $t_{\text {tabel }}$ & kesimpulan \\
\hline 1 & Kelaseksperimen & 51,66 & & & Kemampuanawalsama \\
\cline { 1 - 3 } & Kelascontrol & 45,66 & 1,51 & 2.00 & \\
\hline
\end{tabular}

Berdasarkan tabel 4.5 diatas, hasil pemberian pretes pada kelas eksperimen dan kelas control diperoleh nilai rata-rata kelas eksperimen adalah 51,66 dan kelas control adalah 45,66. Perhitungan uji t dua pihak dengan nilai rata-rata pretes kelas eksperimen dan kelas control untuk $\alpha=0,05$, dapat disimpulkan bahwa 
kemampuan awal siswa pada kelas eksperimen dan kelas control sama. Perhitungan uji hipotesis penelitian kemampuan awal (pretes) dapat dilihat pada lampiran 14.

2. Pengujian kemampuan akhir (posttest)

Tabel4.6 hasilujihipetesisnilaipos test

\begin{tabular}{|c|c|c|c|c|c|}
\hline No & Data kelas & Nilai rata-rata & $t_{\text {hitung }}$ & $t_{\text {tabel }}$ & Kesimpulan \\
\hline 1 & $\begin{array}{c}\text { odel pembelajaran Time } \\
\text { Token }\end{array}$ & 78,83 & \multirow{2}{*}{1,89} & 1,67 & $\begin{array}{c}\text { Semampuanakhir } \\
\text { berbeda }\end{array}$ \\
\cline { 1 - 3 } 2 & $\begin{array}{c}\text { Model pembelajaran } \\
\text { lamgsung }\end{array}$ & 75,5 & & \\
\hline
\end{tabular}

Setelah siswa kelas eksperimen diberikan perlakuan, maka hasil pemberian post test pada kelas eksperimen dan kelas control diperoleh nilai rata-rata kelas eksperimen adalah 78,83 sedangkan kelas control adalah75,5. Berdasarkan uji statistik (uji t satu pihak) diperoleht $t_{\text {hitung }}$ $=1,89$. Pada taraf nyata $\alpha=0,05$, dan $\mathrm{dk}$ $\left(n_{1}-n_{2}\right)-2$

diperoleh $t_{\text {tabel }} 1,67$ karenat $_{\text {hitung }}>t_{\text {tabel }}$ $(1,89>1,67)$ maka hipotesis yang diajukan bahwa ada pengaruh model pembelajaran Time Token terhadap hasil belajar siswa pada materi pokok menapaki jalan terjal penegakan HAM di Indonesia di kelas XI semester I SMA NEGERI SIPAHUTAR TAPUT T.A 2020/2021 dapat diterima kebenarannya..

\section{E. PembahasanHasilPenelitian}

Hasil penelitian menunjukkan bahwa ada pengaruh model pembelajaran Time Token terhadap hasil belajar siswa pada materi pokok menapaki jalan terjal penegak HAM di Indonesia di kelas XI smester I SMA NEGERI SIPAHUTAR TAPUT T.A 2020/2021 . Karena melalui model pembelajaran time token siswa lebih aktif mendengarkan serta mengeluarkan pendapat sehingga suasana kelas tidak beku/diam sama sekali. Model pembelajaran Time Token juga memudahkan siswa untuk mengingat dan mempelajari materi yang telah diajarkan.

Sebelum melakukan tindakan, peneliti melakukan pretes untuk mengetahui seberapa jauh pemahaman mereka tentang materi yang akan disampaikan saat penelitian. Dan dari analis ahasil pretes memang diperlukan tindakan untuk meningkatkan hasil belajar mereka dalam mata pelajaran PKn,

Untuk mengetahui adanya peningkatan hasil belajar dapat dilihat dari meningkatnya prestasi keberhasilan siswa dari observasi awal sebelum sampai dilakukannya tindakan. Pada awal pertemuan peneliti mengadakan pretes dan dilihat dari hasil tes tersebut menunjukkan bahwa nilai masih terlihat sangat rendah. Hal ini disebabkan oleh guru masih menerapkan model pembelajaran yang biasa.

Setelah peneliti melakukan pretes, peneliti langsung melakukan tindakan dengan menyampaikan materi dengan menggunakan model pembelajaran time token dan melakukan postes supaya mengetahui adanya peningkatan terhadap hasil belajar siswa. Selama proses pembelajaran dengan menerapkan model pembelajaran time token terjadi peningkatan hasil belajar. Peningkatan hasil belajar dapat dilihat dari nilai tes awal (pretes) dan nilai tes akhir (postes).

\section{SIMPULAN}

\section{A. Simpulan}

1. Hasil belajar siswa yang diajarkan dengan menggunakan model pembelajaran Time Token pada materi pokok menapaki jalan terjal penegakan HAM di Indonesia di kelas XI semester I SMA NEGERI SIPAHUTAR TAPUT T.A 2020/2021 adalah78,83.

2. Hasil belajar siswa yang diajarkan dengan menggunakan model pembelajaran langsung pada 
materi pokok menapaki jalan terjal penegakan HAM di Indonesia di kelas XI semester I SMA NEGERI SIPAHUTAR $\begin{array}{lll}\text { TAPUT } & \text { T.A } & 2020 / 2021\end{array}$ adalah75,50.

3. Ada pengaruh yang signifikan penggunaan model pembelajaran Time Token terhadap hasil belajar siswa pada materi pokok menapaki jalan terjal penegakan HAM di Indonesia di kelas XI semester I SMA NEGERI SIPAHUTAR TAPUT T.A 2020/2021 hal ini ditunjukkan dengan hasil uji statistic (uji t) $t_{\text {hitung }}>t_{\text {tabel }}(1,89>1,67)$.

\section{B. SARAN}

Adapun saran yang diberikan peneliti yaitu

1. Dengan memakai model pembelajaran time token kepada siswa dapat membuat siswa lebih berani mengeluarkan pendapat, sehingga membuat hasil belajar siswa agar lebih meningkat.

2. Bagi guru PKn yang ingin mengajar sebaiknya menggunakan model pembelajaran agar memperoleh hasil belajar yang baik.

3. Kepada peneliti selanjutnya yang ingin meneliti permasalahan yang sama disarankan melakukan penelitian denga nmenggunakan materi yang berbeda serta terlebih dahulu memperhatikan dan melihat karakter siswa.

\section{DAFTAR PUSTAKA}

Arikunto, (2010). Prosedur

Penelitian,Jakarta : Rineka Cipta (2012). Prosedur

Penelitian,Jakarta : Rineka Cipta

Dimiyati dan Mudjiono, (2013). Belajar Dan Pembelajaran, Jakarta: Rineka Cipta Fathurrohman, (2015). Model-model Pembelajaran Inovatif, Yogyakarta : Ar-Ruzz Media

Huda, (2013). Model-model pengajaran dan pembelajaran, Yogyakarta: Pustaka Pelajar.

Panjaitan Binsar,(2012). Prosedur Penelitian, Medan : Poda

Purwanto, (2011).Evaluasi Hasil Belajar, Yogyakarta : Pustaka Belajar

Shoimin Aris, (2016). 68 Model Pembelajaran Inovatif dalam Kurikulum 2013, Yogyakarta: ArRuzz Medi

Slameto, (2010). Belajar Dan FaktorFaktor Yang Mempengaruhi, Jakarta: Asdi Mahasatya

Sudarwan Danim, (2010). Pengantar kependidikan, Bandung: Alfabeta

Sudjana, (2014). Metode Statistik. Bandung : Tarsito

Sugiono, (2013). Statistik Untuk Penelitian, Bandung : Alfabeta

Susanto Ahmad, (2016). Teori Belajar Dan Pembelajaran, Jakarta: Prenada Medi 